\title{
WACANA “KERAJAAN MAJAPAHIT BALI”: DINAMIKA PURI DALAM PUSARAN POLITIK IDENTITAS KONTEMPORER
}

\section{Putu Gede Suwitha}

Departemen Sejarah, Fakultas Ilmu Budaya,

Universitas Udayana, Denpasar - Indonesia

Alamat korespondensi: putu_suwitha@yahoo.co.id

Diterima/Received: 10 Agustus 2018; Direvisi/Revised: 17 Januari 2019; Disetujui/Accepted: 14 Maret 2019

\begin{abstract}
This study discusses the transformation of the identity of the contemporary Balinese community and the dynamics of palaces (puri) in the political rotation based on discursive development of the "Bali Majapahit Kingdom". The discourse can be observed from the local newspapers in Bali such as Bali Post, Tokoh, and so forth. The discourse of the "Bali Majapahit Kingdom" inspired by the Majapahit kingdom as the image. The historical method applied in this study. The data were analyzed descriptively-qualitatively using historical analysis. The result of the study shows that the discourse of the "Bali Majapahit Kingdom" has been thrown by a central figure named Aryawedakarna for his political interest. He has smartly used the Majapahit kingdom and the resurgence of Hinduism as the inspiration to establish the image as a royal figure. Actually, what he has done is the political identity and was successfully appointed a member of the Regional Representative Council [Dewan Perwakilan Daerah] with more or less 200,000 votes in the 2014 election.
\end{abstract}

Keywords: Politic of Identity; Dynamic of Palaces; Politic of Image.

\begin{abstract}
Abstrak
Kajian ini membahas perubahan identitas masyarakat Bali Kontemporer, khususnya perkembangan puri dalam pusaran politik dengan mengikuti perkembangan wacana "Kerajaan Majapahit Bali”. Wacana ini dapat diamati lewat media pers di Bali khususnya koran Bali Post, Tokoh, dan beberapa koran lainnya. Wacana “Kerajaan Majapahit Bali”, sesungguhnya mengambil Kerajaan Majapahit sebagai inspirasi untuk pencitraan. Kajian ini dilakukan dengan menggunakan metode dan analisis historis. Semua data yang terkumpul diolah secara deskriptif-kualitatif. Hasil studi menunjukkan, bahwa kemunculan wacana "Kerajaan Majapahit Bali", merupakan wacana yang dilemparkan oleh tokoh sentralnya Aryawedakarna untuk kepentingan politik. Wedakarna dengan cerdas mengambil Kerajaan Majapahit dan kebangkitan Hindu sebagai inspirasi dalam membangun citra diri sebagai tokoh puri. Wedakarna sesungguhnya melakukan politik identitas dan berhasil terpilih sebagai anggota Dewan Perwakilan Daerah (DPD) dengan dukungan suara kurang lebih 200.000 suara dalam Pemilu 2014.
\end{abstract}

Kata Kunci: Politik Identitas; Dinamika Puri; Politik Pencitraan.

\section{PENDAHULUAN}

Masyarakat Bali bergerak sangat dinamis kalau dilihat dari perjalanan sejarahnya. Pada mulanya Bali sangat ketinggalan dibandingkan dengan masyarakat Jawa dan Sumatera. Pada 1908, di Jawa sudah lahir organisasi modern Budi Utomo, sedangkan di Bali masih terjadi Perang Puputan (1906, 1908). Pada 1965, masyarakat Bali saling bunuh hanya karena berbeda partai politik, yaitu antara pendukung Partai Nasional Indonesia (PNI) dan Partai Komunis Indonesia (PKI) (Robinson, 2006: 417-438). Selanjutnya, pada 1971 terjadi pula Golkarisasi; terjadi pembakaran banyak rumah penduduk yang notabene pendukung PNI dan beberapa kasus pembunuhan. (Suryawan, 1988). Pada 1998, ketika Megawati 
gagal menjadi Presiden, terjadi gejolak politik dan pembakaran gedung-gedung pemerintah di Bali.

Di sisi lain, masyarakat Bali juga mengalami perubahan dan kemajuan dengan cepat akibat pertumbuhan sektor pariwisata. Punggawa Ubud Tjokorda Gde Raka Sukawati tampil sebagai salah seorang pelopor pariwisata. Tjokorda yang merupakan seniman dan impresario tari, yang nantinya menjadi presiden Negara Indonesia Timur (NIT) sejak kembali dari misi kesenian (Pameran Seni) di Paris pada 1931, kemudian mengundang tamu-tamu asing untuk datang ke Puri Ubud. Para pelayan ( $a b d i$ ) diminta melayani para tamu dengan senyum dan kepala tegak, berbeda dari sebelumnya yang melayani para bangsawan di puri dengan sikap selalu membungkuk. Seninam, ilmuwan, pesohor kemudian datang ke Puri Ubud sebagai wisatawan. Memang sebelumnya, sejak 1911, orang asing sudah datang ke Puri Ubud, tetapi pariwisata Bali khususnya di Ubud mulai maju sejak 1920-an. Pada 1924, dibuka pelayaran mingguan ke pelabuhan Buleleng. Pada 1928, Konninklijke Paketvaart Matschappij (KPM) membuka Bali Hotel di Denpasar (Sendra, 2015: 116). Kemajuan pariwisata di Bali tidak dapat dilepaskan dari tokoh lain yaitu Tjokorda Gde Agung Sukawati, yang merupakan adik kandung dari Tjokorda Gde Raka Sukawati (Hilbery, 1979).

Kedua tokoh ini kemudian meminta masyarakat untuk meniru dan belajar dari orangorang Barat, sehingga masyarakat Bali menjadi kreatif, mudah belajar, mandiri, dan mudah menerima sesuatu menjadi miliknya sendiri. Akhirnya lukisan-lukisan Bali semakin baik dan berkualitas. Tari-tarian Bali juga mulai berkembang pesat, karena para penari Bali berkolaborasi dengan penari-penari atau seninamseniman asing. Persepsi masyarakat Bali terhadap laut juga mengalami perubahan. Laut dalam perspektif masyarakat Bali cukup ditakuti dan dihindari. Dahulu, masyarakat Bali adalah masyarakat agraris dan jauh dari laut. Sejak pertumbuhan pariwisata, masyarakat Bali justru lebih dekat dengan laut; mereka mengenal diving dan berenang. Masyarakat Bali juga dikenal dekat dengan kekuasaan. Dari masa pemerintahan Presiden Sukarno sampai dengan Presiden Joko Widodo, hampir selalu terdapat orang Bali yang mendapat kepercayaan menjadi menteri dalam kabinet.

Kajian tentang peranan puri di beberapa pusat perkembangan di Bali telah dilakukan oleh beberapa pihak. Mahadewi (2017) melihat eksistensi puri masih dipandang sebagai identitas para bangsawan tradisional Bali. Sejak dahulu hingga saat ini, anggota puri banyak yang memiliki karir politik dan berafiliasi dengan kekuatan politik tertentu. Hal ini juga merupakan salah satu strategi puri sebagai identitias masyarakat Bali dapat bertahan. Beberapa puri besar di Bali seperti Puri Agung Denpasar, bahkan telah mulai beradaptasi mengikuti modernisasi dan perubahan sosial ekonomi yang terjadi. Sementara itu, peranan anggota puri dalam politik sebagai bagian dari usaha pemertahanan eksistensi dikuatkan juga oleh Suwitha (2012). Meskipun para elite puri memilih untuk berpolitik praktis, mereka merupakan pihak yang sangat berpengaruh dan dipercaya di masyarakat. Keterlibatan elite puri dalam pemerintahan atau partai politik merupakan fenomena yang marak sejak 2004. Berdasar pada beberapa kajian yang telah dilakukan, artikel ini lebih menitikberatkan peranan puri dan elitenya dalam politik di masa kontemporer dengan mengusung penguatan identitas Hindu dan wacana “Kerajaan Majapahit Bali”.

Artikel ini disusun dengan mengumpulkan sumber-sumber berupa koran, majalah, dan buku. Koran yang dianalisis khususnya Bali Post yang terbit di Bali antara 2015 sampai 2018, serta majalah Tokoh. Beberapa kajian yang menjadikan Majapahit sebagai inspirator adalah karya Supono (1983), Mulyana (1979), dan Pranajaya (2015). Semua data yang terkumpul dianalisis secara historis-kualitatif.

\section{KEBANGKITAN PURI}

Puri (istana, keraton), berasal dari kata pur, yang artinya benteng pertahanan. Keberadaan Puri di Bali bermula dari ekspansi Kerajaan Majapahit pada 1343. Sampai saat ini tidak ditemukan sisa keraton (puri) raja-raja yang memerintah Bali sebelum 1343. Raja Bali yang terdahulu sebelum dikalahkan Majapahit-Sri Asta Sura Ratna Bumi Banten tidak meninggalkan jejak keraton yang diperkirakan di sekitar Pejeng-Bedahulu sekarang 
(Sidemen, 2010: 77). Menurut berbagai sumber babad, ${ }^{2}$ setelah Bali dikuasai oleh Majapahit, diangkatlah penguasa Bali, Sri Kresna Kepakisan yang berkedudukan di Puri Samprangan dekat Gianyar sekarang. Samprangan menjadi pusat pemerintahan Bali yang baru, karena tempat itu bekas markas tentara Majapahit (Gajah Mada) ketika menaklukkan raja Bali Sri Astasura yang berkedudukan di Bedahulu (Mirsha, 1986: 123; Putra, 2012:14).

Pada masa pemerintahan Raja III Dalem Ketut Ngelesir atau Semara Kepakisan (13831459), ia memindahkan purinya ke Gelgel pada 1383. Raja Ngelesir oleh Tjokorda Raka Putra (2015: 60) dikatakan keturunan II (Undag II). Istananya bernama Puri Baru Sweca Pura atau Lingarsaa Pura (Munandar, 2005: 138). Selanjutnya Puri Gelgel berperan sentral sebagai penguasa tunggal di Bali, bahkan utusan Belanda di bawah Cornellis de Houtman menyinggahi Gelgel pada 1597. Pada masa pemerintahan Dalem Segening 1580-1665, peranan Puri Gelgel semakin besar dan bahkan Raja Segening berkuasa sampai Blambangan, Lombok, dan Sumbawa. Dalem Segening pada 1624 mengadakan perjanjian tentang pembagian wilayah sebelah timur dengan Kerajaan Makassar. Sumbawa kemudian dikuasai Makassar dan Lombok dikuasai Kerajaan Gelgel (Putra, 2015: 138).

Sejak pemerintahan Dalem Dimade (16331651) terjadi kemelut di istana Gelgel, karena beberapa petinggi kerajaan berusaha memberontak. Bahkan sejak 1651, Ki Agung Maruti merebut kekuasaan dan sepenuhnya menguasai Gelgel. Raja Dalem Dimade mengungsi ke Desa Guliang, demikian pula bangsawan tinggi kerajaan mengungsi ke luar Gelgel. Pada 1686, pasukan gabungan bekas punggawa Kerajaan Gelgel-Dewa Agung Jambe menyerang balik Maruti. Maruti mengalami kekalahan pada 1687. Menurut de Graaf, pada 1686 Maruti masih melakukan kontak melalui surat dengan Verenigde Oost-Indische Compagnie (VOC). Pada 1687 VOC mengirim surat kepada Maruti, namun dijawab oleh Dewa Agung Jambe. Selanjutnya, Dewa Agung Jambe memindahkan Puri Gelgel ke Klungkung. Selanjutnya setelah Kerajaan Gelgel runtuh, Bali terpecah menjadi beberapa kerajaan kecil, tetapi masih mengakui Kerajaan Klungkung secara moral, karena dianggap pewaris Majapahit (Sidemen, 1983: 53).

Setelah kekalahan Maruti pada abad ke-17 dan muncul puri-puri baru (kerajaan baru) baik yang didirikan oleh Keturunan Raja Gelgel (Ksatria Dalem) maupun para arya (bangsawan) yang mengiringi Kresna Kepakisan. Secara umum pendirian puri-puri ini didasari oleh sejarah yang sama yaitu mempertahankan kesinambungan pengaruh Majapahit. Bahkan, keraton Majapahit menjadi acuan bagi pembangunan puri-puri selanjutnya. Puri Agung Klungkung adalah puri yang tertua di Bali setelah Gelgel yang dibangun megah sesuai dengan apa yang diuraikan dalam Kitab Nagara Kertagama. Dari aspek sosial puri merupakan tempat tinggal raja yang berkuasa atas seluruh kerajaan, sedangkan dari aspek politik, puri adalah pusat pemerintahan kerajaan (Munandar, 2005: 13).

Puri dianggap sebagai simbol kekuasaan politik raja. Oleh karena itu, raja tidak bersedia mempertahankan simbol kekuasaannya yang pernah dikuasai musuh, karena dianggap sebagai musibah. Sehubungan dengan itu, raja membuat atau membangun simbol kekuasaan baru. Sebagai contoh Puri Gelgel; puri itu ditinggalkan, karena raja tidak mau lagi beristana di Gelgel. Raja kemudian membangun puri baru di Klungkung yang disebut Smarapura. Hal ini juga sering terjadi di Jawa yaitu terjadi perpindahan ibu kota sejak periode Hindu-Buddha sampai periode perkembangan kerajaan-kerajaan Islam (Munandar, 2005: 199). Kehidupan sistem politik dengan ikon puri rupanya merupakan gejala yang umum di Asia Tenggara pada zaman itu. Raja tidak bisa dipisahkan dengan istana. Puri adalah milik raja, tidak satu pun yang dapat berdiri tanpa ada istana (Geldern, 1982: 29-30).

Setelah disintegrasi Kerajaan Gelgel sejak abad ke-18 (sering disebut zaman raja-raja dan seterusnya sampai abad ke-20), puri makin berkembang dengan sistem feodalisme sebagai ikutannya. Kerajaan Bali bersifat sentrifugal, raja mempunyai kekuasaan sendiri (independen). Creese (1993:30) menyebut struktur pemerintah di Bali dengan galaksi, dan Klungkung sebagai pusat dikelilingi oleh raja-raja lain. Ilustrasinya tampak pada Gambar 1. 


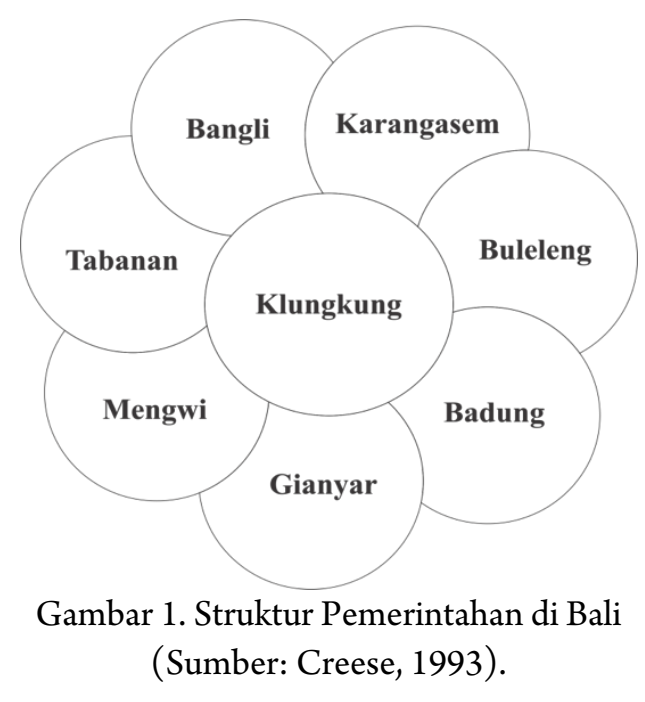

Bali kemudian terpecah menjadi beberapa kerajaan yang masing-masing berdaulat dengan puri-purinya. Belum lagi puri-puri yang berada di bawah kerajaan pusat seperti Puri Ubud bagian dari Puri Gianyar dan sub-subpuri lainnya. Raja Klungkung secara simbolis dianggap sebagai pemersatu karena keturunan langsung dari Majapahit (Ksatrya Dalem). Sejak pertengahan abad ke-19 puri-puri dimanfaatkan oleh Belanda dalam membentuk pemerintahan tidak langsung di Bali.

Periode abad ke-18-19 terjadi rivalitas dan perang antarkerajaan di antara 10 kerajaan di Bali. Pada awal abad ke-18 muncul hegomoni Kerajaan Buleleng yang dilanjutkan dengan Kerajaan Mengwi. Pada abad ke-19 tampil kerajaan lain seperti Karangasem dan Badung. Kerajaan Klungkung kerap menjadi aktor permusuhan antarkerajaan (Agung, 1989), meskipun demikian secara militer Klungkung tidak cukup kuat.

Dinamika wilayah kerajaan dengan puripurinya sangat menarik untuk diamati. Terjadi pengambilan beberapa wilayah kerajaan oleh kerajaan lain, seperti beberapa wilayah Kerajaan Mengwi diambil oleh Bangli, Badung, dan Tabanan (Nordholt, 2006: 248). Di lain pihak, ada penyatuan antara satu kerajaan dengan kerajaan lain untuk menjadikan kekuasaan lebih besar. Kerajaan Buleleng diserahkan kepada Kerajaan Bangli, tetapi dikembalikan lagi kepada Belanda. Sementara itu, Kerajaan Gianyar digabung dengan Kerajaan Klungkung (Agung, 1989: 373, 405). Kemudian Kerajaan Mengwi dan Kerajaan
Payangan lenyap karena peperangan dan hilang dalam konstelasi politik kerajaan di Bali.

Seperti diketahui, puri merupakan simbol kekuasaan dan sarat dengan politik-politik penyatuan dengan puri-puri lain dan politik penyatuan dengan kekuatan Belanda. Politik kekuasaan mulai dilakukan puri-puri pada abad ke19. Adapun Kerajaan Buleleng berhasil dikalahkan oleh Belanda pada 1849. Sebetulnya, Belanda pada saat itu sudah melirik raja-raja Bali untuk menegakkan Pax Neerlandica, namun masih mencari alasan politik untuk dapat menguasai mereka.

Sebaliknya puri mulai berani mencoba "bermain" politik untuk memperbesar kekuasaan, suatu hal yang berbeda dari zaman sebelumnya, bahwa puri cenderung tertutup. I Gusti Ngurah Kesiman Raja Badung mengawali berkolaborasi dengan Belanda dari kekuatan asing lainnya untuk membangun ekonomi Badung. Era peperangan antara raja-raja Bali rupanya sudah mulai disadari sangat menguras tenaga. Kedelapan kerajaan seperti yang disebutkan oleh Creese (1993) sempat mengadakan perjanjian tidak saling menyerang. Perjanjian antara delapan kerajaan dikenal dengan nama Paswara Asta. Kolaborasi dengan kekuatan asing kemudian juga dilakukan oleh puri-puri Ubud, Gianyar maupun Puri Karangasem dalam bidang sosial-politik, kebudayaan, maupun pendidikan.

Pada masa kemerdekaan suatu loncatan terjadi di level nasional akibat hasil pendidikan Barat. Tokoh Puri Ubud, Puri Carangsari (I Gusti Ngurah Rai), Puri Tabanan, dan sebagian kecil masyarakat Bali telah "mewarnai" kehidupan politik di level nasional. Akan tetapi, tidak dapat disangkal bahwa terjadi persaingan antarpuri untuk memperebutkan hegemoni kekuasaan. Beberapa contoh persaingan antarpuri di Denpasar yaitu antara Puri Satrya dengan Pemecutan, dan di Gianyar antara Puri Gianyar dan Ubud dan yang lain (Robinson, 2006: 150163).

Setelah proklamasi kemerdekaan terjadi euforia revolusi yang menuntut persamaan dan keterbukaan. Pada masa ini mulai dikenal sebutan "bung" seperti di Jawa. Sebutan "bung" mengandung makna dan nilai demokratis yang mengarah pada kebebasan, dalam hal ini 
kebebasan dari feodalisme yang merupakan tujuan revolusi. Bupati pada awal-awal kemerdekaan seperti Bupati Hartawan Mataram dari Buleleng tidak pernah menyebutkan titel kebangsawanannya. Masyarakat menyebut Bung Hartawan Mataram. Puri-puri perjuangan juga berfungsi sebagai pelopor modernisasi.

Suatu titik balik terjadi ketika pemilihan Gubernur Bali pada 1960. Calon Gubernur dari golongan jaba memenangkan pemilihan yaitu I Nyoman Mantik yang pada saat itu mengalahkan tokoh puri Anak Agung Bagus Suteja. Suatu hal yang mengherankan, Presiden Sukarno justru melantik Anak Agung Bagus Suteja meskipun kalah dalam pemilu. Sukarno ternyata masih berkiblat kepada tokoh puri. Dalam konteks ini, Sukarno dianggap telah melakukan kesalahan fatal. Sukarno tidak membangun kehidupan politik Bali yang benar dan bahkan kesannya memperkuat praktik feodalisme.

Sukarno memilih membangun Bali secara ekonomi dan mengabaikan pembangunan politik. Salah satu buktinya ia membangun Hotel Bali Beach di Sanur dengan pembiayaan dari hasil rampasan perang Jepang. Dengan pembangunan ekonomi terutama pariwisata, Bali dapat berubah. Akan tetapi, di pihak lain feodalisme sepertinya masih berkembang dengan pembangunan puripuri yang megah. Upacara-upacara keagamaan juga dilakukan secara megah. Ada benarnya Geertz (1980: 130) menyatakan Bali seperti teater state. Raja hidup dalam suasana dan nuansa panggung sandiwara dan upacara-upacara kebesaran di puri. Pada masa kemudian, eksistensi dan hegemoni puri makin berkembangan. Sementara itu, masyarakat Bali mengalami perkembangan feodalisme ke dalam dan tertutup. Sistem feodalisme Bali yang tertutup menyebabkan tidak ada peluang untuk mobilitas vertikal; tidak seperti di Jawa yang meningkatkan terjadi mobilitas vertikal.

Puri-puri sejak akhir abad ke-19 telah dimanfaatkan oleh Belanda dan berkolaborasi untuk mempertahankan kekuasaannya. Ketika Netherlands Indies Civil Administration (NICA) datang lagi ke Bali pada 1946, ia memanfaatkan kawan lamanya yaitu elite puri-puri. Dengan demikian, pada zaman revolusi ada sebutan Puri Pejuang dan Puri Anti-Pejuang. Pada zaman kepartaian di Bali, puri-puri juga dimanfaatkan oleh partai politik seperti PNI, Partai Sosialis Indonesia (PSI), dan Golongan Karya (Golkar). Puri Satriya mengusung PNI, dan pada masa kemudian Partai Demokrasi Indonesia Perjuangan (PDIP), sedangkan Puri Pemecutan berkiblat ke PSI dan Golkar. Partai-partai yang memanfaatkan puri dianggap tidak berhasil. Kondisi ini menyebabkan kehidupan partai-partai tidak sehat, karena pada waktu itu partai-partai terlalu bergantung pada puri dan cenderung tidak ada ruang untuk membangun kaderisasi. Kehadiran partai-partai politik setelah reformasi pada kenyataannya justru hanya membuat perpecahan, seperti kejadian pada 1965 dan 1971. Sampai saat ini, tepatnya setelah revolusi 1954, tidak ada perubahan atau inovasi dalam kehidupan politik. Ketika terjadi reformasi misalnya, kehidupan politik Bali mengalami keterkejutan. Hal itu karena masyarakat sipil dan masyarakat kelas menengah di Bali tidak atau bahkan belum terbentuk, sehingga untuk pembangunan politik, terutama era pemilihan langsung kepala daerah, masyarakat Bali masih berkiblat kepada puri dan tokoh puri.

Tokoh puri memang mempunyai tradisi kekuasaan sejak zaman raja-raja. Sejak reformasi ada kecenderungan yang menarik dalam budaya politik yaitu munculnya wacana-wacana yang ingin menampilkan tokoh puri dalam suksesi kepemimpinan yang sudah lama dilupakan. Elite puri masih dianggap sebagai simbol yang mempunyai kuasa moral dan penjaga moral masyarakat yang sedang mengalami euforia kebebasan yang sudah lama terbelenggu oleh pemerintahan otoriter Orde Baru. Meminjam pendapat Michel Foucault, ada relasi kuasa timbal balik antara puri dan masyarakat. Kuasa adalah suatu yang dibutuhkan bagi masyarakat, sepanjang tidak destruktif dan dominatif. Dalam relasi kuasa, tidak ada subordinasi, semuanya memiliki ruang yang bebas. Sumber kuasa menurut Foucault bisa berupa modal budaya yaitu pengetahuan dan kekuatan simbolik, modal politik berupa jaringan sosial dan modal uang (ekonomi). Menurut Bourdieu yang juga merupakan ahli filsafat Perancis, di antara ketiga modal tadi bisa dikonversikan atau dipertukarkan. 


\section{WACANA KERAJAAN MAJAPAHIT BALI}

\section{Identitas Majapahit}

Penaklukan Bali oleh Gajah Mada pada 1343 (Ginarsa, 1968: 1; Yamin, 1957: 47-48) tidak hanya menurunkan derajat Bali dari kerajaan merdeka menjadi taklukan, tetapi juga berdampak dalam bidang sosial-budaya, dalam hal ini lahir stratifikasi masyarakat Bali yang feodal. Sebelumnya masyarakat Bali sudah mengenal stratifikasi sosial, tetapi lebih egaliter dan lebih terbuka. Patih Gajah Mada kemudian menunjuk Sri Kresna Kepakisan (1352-1380) sebagai raja Bali dan beristana di Samprangan, Gianyar. Kresna Kepakisan sebenarnya seorang Brahmana Majapahit yang berasal dari Kediri. Kepakisan bersama 15 (lima belas) orang arya, tiga orang Wesia dan prajurit kaula Jawa yang ikut menyertai raja baru ini membentuk kasta sendiri, yang di Bali kemudian berkembang menjadi wangsa dan soroh (sub-wangsa).

Masyarakat Bali Hindu yang berasal dari Jawa tersusun atas empat wangsa, yaitu Brahmana, Kesatria, Waisya, dan Sudra. Sebagai penguasa (elite pemerintah), Kresna Kepakisan dan keturunannya menempati tingkat wangsa Kesatria yang tertinggi yang disebut Ksatrya Dalem. Para arya Jawa dan keturunannya menempati tingkat wangsa kesatria yang disebut arya. Wangsa Waisya ditempati oleh keturunan Ton Kober, Tan Kaur, Tan Mundur, Wangsa Sudra ditempati oleh bekas prajurit Majapahit dan rakyat Jawa yang membaur dengan rakyat Bali asli.

$\begin{array}{ccc}\text { Dominasi } & \text { Majapahit } & \text { kemudian } \\ \text { menimbulkan dualisme dalam } & \text { pelapisan }\end{array}$ masyarakat Bali yaitu antara masyarakat Bali Hindu (wong Majapahit) dan Bali Aga (Bali asli). Masyarakat asli (Bali $\mathrm{Aga}$ ) dianggap tidak memiliki sistem kewangsaan, karena sudah diturunkan derajatnya (dipetita) menjadi rakyat biasa karena kalah perang. Sistem kewangsaan hanya berlaku untuk masyarakat Bali Hindu dengan dominasi bangsawan - Jawa (Djlantik, 1937: 17-18).

Kresna Kepakisan diganti oleh putranya Agra Samprangan (hanya sebentar) dan seterusnya diganti oleh Dalem Ketut Ngelesir (1380-1400), yang memindahkan keratonnya ke Gelgel (Klungkung). Dalam Sejarah Bali, Kerajaan
Gelgel kemudian menjadi kerajaan besar yang berhubungan dengan VOC dan Kerajaan Makassar. Gelgel menguasai Lombok dan Blambangan, tetapi masih tetapi di bawah Majapahit.

Rupanya sejak periode Gelgel ini, stratifikasi masyarakat Bali berkembang makin rumit. Stratifikasi sosial berkembang ke dalam, karena sudah menjadi wangsa (golongan) dan saroh yang menyerupai kasta yang sangat tertutup. Tidak ada mobilitas vertikal sama sekali. Nantinya kerajaan Gelgel menganggap diri sebagai pelanjut kebesaran Majapahit, terutama dalam bidang pengayoman agama Hindu. Dalam identitas kontemporer fungsi ini dilanjutkan dalam abad ke21 oleh "Kerajaan Majapahit Bali" (Bali Post, 23 Agustus 2016).

Perkembangan Ksatrya Dalem keturunan langsung dari Kresna Kepakisan dan pesebaran keluarganya dari generasi ke generasi menunjukkan gelar atau identitas yang khas. Ksatrya Dalem adalah keturunan vertikal raja, memakai gelar I Dewa Agung (raja), I Dewa untuk laki-laki dan I Dewa Ayu untuk perempuan dan beberapa variannya tergantung dari isteri.

Para arya yang mengikuti Kresna Kepakisan (raja), yang kemudian diberi jabatan strategis -diberi gelar yaitu I Gusti atau I Gusti Agung untuk laki-laki, I Gusti Ayu untuk perempuan beserta variannya tergantung isteri. Para Waisya diberi gelar gusi atau $\mathrm{Si}$, yang nantinya menjadi Gusti, karena Gusi atau Si dianggap kurang tinggi.

Pemakaian gelar-gelar baru memperlihatkan kebijakan politik Gajah Mada dengan membentuk golongan bangsawan baru. Salah satu tujuannya adalah untuk memperoleh jaminan kesetiaan pengabdian terhadap kekuasaan Majapahit. Strategi ini kemudian dilakukan oleh Belanda pada abad ke- 20 tepatnya pada 1920, dengan memberikan gelar baru bagi keturunan bangsawan dari Ksatrya Dalem yang menjadi regent (bupati) di wilayah Bali dengan gelar baru Anak Agung atau Cokorda (Staatsblad 1920). Regent Badung, Tabanan, dan Klungkung memakai gelar Cokorda. Regent Jembrana, Buleleng, Bangli dan Gianyar memakai gelar Anak Agung. Regent Karangasem memakai gelar Anak Agung Agung. Kemudian beberapa raja bawahan seperti Ubud juga memakai gelar Cokorda dan Anak Agung. Gelar Dewa dan 
Gusti mulai ditinggalkan karena dianggap kurang tinggi.

Sekarang dalam praktik kehidupan sistem sosial masyarakat Bali masih menunjukkan sistem kasta; masih terjadi dualisme yang sangat berpengaruh antara Bali pegunungan dan Bali dataran. Sistem banjar masih berbeda, sistem penguburan, sistem pengabenan, sistem kependetaan, pergaulan, masih menganut sistem kasta belum egaliter. Pada masa revolusi dan perjuangan antara 1945-1950 sempat terjadi persamaan seperti sebutan "bung" yang menunjukkan demokratisasi dan egalitarisme. Setelah itu terjadi lagi penguatan triwangsa sampai sistem keorganisasian agama terpecah (Parisada Pecah), Universitas Agama juga pecah.

Sekarang dalam pergaulan informal seharihari dalam interaksi dengan orang yang belum dikenal, orang akan menanyakan status kebangsawanan "antuk linggih", bertanya dari kelompok mana anda. Setelah diketahui, baru diserasikan berinteraksi. Dalam teori, di Bali tidak ada kasta, tetapi kenyataan masyarakat Bali masih berkasta, bahkan tertutup dari mobilitas. Sampai sekarang orang Bali masih mencari-cari legitimasi keturunan salah satu arya dari Majapahit, Kediri atau Jawa. Orang bangga keturunan Majapahit. Wacana ajeg Bali sesungguhnya ada kesan menyanjungkan kasta dan mempertahankan sistem kasta (Wijaya, 2009).

Majapahit memerlukan sembilan tahun untuk menaklukkan Bali, itu pun dengan tipu daya. Pada 1343 dan 1380, Bali dapat ditundukkan dengan pengangkatan Raja Bali. Perlawanan terus terjadi dan kelompok masyarakat Bali yang tidak bisa menerima Majapahit mengungsi ke pegunungan Bali. Meskipun Majapahit merangkul beberapa tokoh Bali Aga seperti beberapa Bendesa dan Pasek, tetapi perlawanan masih tetap ada, sehingga ada katagori Triwangsa dan Jaba Wangsa yang saling berlawanan. Triwangsa versus Jaba Wangsa sampai masuk ke dalam beberapa ranah seperti bidang pendidikan, politik, bahkan sampai saat ini masih kelihatan.

Kelompok Triwangsa ini mencari akar-akar leluhurnya sampai ke Majapahit. Triwangsa dibedakan antara keturunan langsung raja (Dalem), sehingga dikenal Kesatrya Dalem dan Ksatrya. Hegemoni kelompok kesatria terhadap kelompok Jaba masuk ke dalam hampir semua ranah-ranah kehidupan. Motor perlawanan (kontra hegemoni) kelompok Jaba dimotori oleh kelompok Pasek yang jumlahnya tujuh klen, sehingga sering diplesetkan dengan nama "seven up".

Kerajaan Majapahit memang tidak ada lagi, sejak ratusan tahun yang lalu tepatnya pada 1478 . Namun, semangat kebangkitan Majapahit -identitas Majapahit masih ada. Gejala ini adalah bagian dari politik identitas kontemporer Bali, yang menandai era baru dan kebangkitan baru. Era baru ini dipelopori oleh seorang anak muda terpelajar dan cerdas yang sudah bergelar doktor dalam umur 27 tahun yang bernama Dr. Arya Wedakarna, M. Si. Wedakarna berhasil "membius" masyarakat Bali dengan simbol-simbol identitas yang beragam seperti "The Hindu Center, The Sukarno Center, identitas nasional (senator) sebagai "Raja Majapahit Bali”. Wedakarma bergelar Abhiseka Raja Majapahit Bali, Sri Wilatikta Tegeh Kori Kresna Kepakisan XIX dan berkedudukan di Istana Manca Warna yang terletak di Tampak Siring, Kabupaten Gianyar Bali, berdekatan dengan Istana Tampak Siring (Bali Post, 1 Juli 2015, Bali Post, 19 November 2015).

Sepertinya Bali sudah dipersiapkan sebagai pewaris Kerajaan Majapahit, baik secara politik maupun ekonomi. Ketika Islam mulai bangkit di Nusantara pada abad ke- 14-15, raja Majapahit mengirim pendeta Hindu-Nirartha untuk mendampingi raja Bali pada waktu itu Dalem Waturenggong. Tugas Pendeta Nirartha sebagai pendeta dan penasihat raja karena pengalaman di Majapahit. Pendeta Nirartha kemudian membangun pura-pura di seluruh perairan Bali yang berfungsi sebagai "benteng" pertahanan untuk melindungi Bali secara politik-spiritual. Mubalig-mubalig Islam yang kemudian datang ke Bali untuk memperkenalkan agama baru diterima dengan baik dan diperlakukan sebagai teman (saudara) dan dilindungi. Raja menerapkan politik budaya dengan merangkul mubalig-mubalig dengan diplomasi tingkat tinggi. Di Bali orang Islam diakui sebagai "warga" atau saudara dan diakomodasi dalam kehidupan kemasyarakatan. Pendekatan budaya ini sekarang menghasilkan Islam yang adaptif dan persaudaraan yang disebut 
ikatan menyama braya (ikatan persamaan dan persaudaraan).

\section{Identitas Hindu}

Wedakarna ditetapkan sebagai raja "Majapahit Bali" pada 31 Desember 2009 dan dilantik di Pura Besakih oleh beberapa pendeta Hindu. Usia pada waktu dilantik 29 tahun dan sudah bergelar doctor (Bali Post, 29 Juli 2015).

Wilayah perjuangan Wedakarna adalah seluruh Nusantara bukan hanya Bali saja. Majapahit menurut senator termuda ini harus bangkit dan yang bisa membangkitkan adalah warih-nya yang masih setia beragama Ciwa-Budha. Saat ini sulit mencari tokoh Bali yang sepantaran dengan Wedakarna. Ini yang disebut dengan wahyu keprabon dalam filosofi Jawa.

Untuk mewujudkan cita-cita menegakkan Majapahit dan Hindu Nusantara, Wedakarna berupaya untuk berkomunikasi dan berusaha mempersatukan puri yang tersebar di Bali. Puri yang jumlahnya ratusan Caba dikontak dengan cara yang santun, salah satunya memberikan hadiah cinderamata yang berupa lampu kristal berwarna. Hadiah lampu khas Eropa itu disebut Candlelier. Hadiah lampu sebagai simbol melambangkan sinar atau cahaya, yang berarti menggalang solidaritas atas warih sejumlah puri di Bali. Puri adalah benteng budaya Bali, Hindu, jika puri hancur, maka Hindu akan hancur. Dalam konsep Hindu, istana harus terang benderang sebagai simbol kemakmuran dan cahaya Dewi Sri (Laksmi).

Upacara-upacara sesuai dengan tradisi Majapahit harus melibatkan sulinggih. Bali harus tetap mempertahankan tradisi leluhur, tetapi harus tetap menunjukkan kesederhanaan. Kewajiban puri adalah memberdayakan sulinggih. Demikian juga dengan kebutuhan ekonomi Hindu adalah mutlak. Dengan menyederhanakan upacara adat dan agama, akan bermuara pada ketahanan ekonomi Hindu.

Sebagai raja "Majapahit Bali", Wedakarna benar-benar menjadi ikon kebangkitan Hindu Nusantara (Majapahit). Kerja senator termuda asal Bali ini menunjukkan hasil yang baik terutama dalam pengembangan kedaulatan umat Hindu di luar Bali. Ia menginisiasi dan kemudian meresmikan The Hindu Center yang didirikan di seluruh provinsi di Indonesia. Pada 28 Juli 2015, ia membuka dan meresmikan The Hindu Center di Sulawesi Utara yang merupakan salah satu pusat tempat bersejarah yang diakui sebagai wilayah pengaruh Kerajaan Majapahit seperti yang disebutkan dalam Kitab Nagara Kertagama (Mulyana, 1979). Menurut Wedakarna, Sulawesi Utara merupakan sebuah daerah yang istimewa dengan toleransi yang tinggi. Itu berarti nilai-nilai Majapahit ada di Sulawesi Utara. Oleh karena itu, The Hindu Center harus bersinergi dengan pemerintah Sulawesi Utara untuk menggali sejarah bangsa dengan nilai-nilai Majapahit dan nilai-nilai Pancasila.

Setelah Sulawesi Utara, Wedakarna meresmikan The Hindu Center of Riau di Kota Pekanbaru. Provinsi Riau merupakan pusat perkembangan Siwa-Budha di Sumatera. Masih di tanah Sumatera, The Hindu Center juga didirikan Sumatera Utara dan kemudian disusul dengan Jawa Barat. The Hindu Center di Jawa Barat juga bertujuan untuk menyelamatkan ajaran leluhur di kerajaan Hindu Pajajaran yang terkenal sebagai kerajaan Hindu terkuat di tanah Jawa (Bali Post, Juni-Juli, 2015: 35). Di Sumatera Utara sendiri The Hindu Center berhasil merevitalisasi Candi Buhal yang lama tersembunyi.

Di Jayapura Wedakarna memperjuangkan setra (kuburan). Wedakarna memohon kepada pemerintah kota Jayapura untuk memberikan izin pendirian setra, karena selama ini umat Hindu di Papua mengeluarkan uang puluhan juta rupiah hanya untuk mengirim jenazah ke Bali, untuk penyelenggaraan upacara karena tidak mempunyai kuburan di Jayapura (Bali Post, Juni-Juli, 2015: 43). Bahkan, The Hindu Center juga didirikan di Ambon dan diresmikan oleh Presiden Joko Widodo, pada 18 Februari 2018 (Bali Post, 19 Maret 2018).

Beberapa tradisi Majapahit kemudian dikembangkan dan direvitalisasi seperti penyucian sejarah leluhur atau peringatan hari ulang tahun keluluran atau sugeng Wiyosan Tinggalan Dalem, upacara Ugadeg Ratu Abiseka (ulang tahun bertahta). Pada 31 Desember 2015 bertempat di istana Mancawarna Tampak Siring diperingati acara keenam (Kaping Nem) Ngadeg Ratu Abhiseka Raja Majapahit Bali Sri Wilatika Tegeh 
Kori Kresna Kepakisna 19 (XIX). Dalam upacara peringatan Ngadeg Ratu dirangkai dengan ruwatan di Yogyakarta dan upacara sedekah bumi di Pelabuhan Ratu Sukabumi (Bali Post, 31 Desember 2015).

Tradisi lain yang dikembangkan lagi dan direvitalisasi oleh Wedakarna adalah upacara hari kelahiran atau Sugeng Wiyosan Tunggalan Dalem. Menurut Wedakarna, dalam sejarah sejak diangkat menjadi raja "Majapahit Bali", setiap tahun secara berturut-turut diadakan upacara Tunggalan Dalem. Upacara Tunggalan Dalem memang sudah musnah sejak sirna hilang kertaning bumi. Namun sejak Wedakarna melinggih dan dijadikan penglingsir oleh umat Ciwa-Budha dan umat Kajawen di seluruh nusantara, upacara ini direkonstruksi kembali. Upacara Sugeng Wiyosan diikuti dengan penyucian pusaka puri (Jamasan), penyucian kereta kencana segara kidul yang merupakan hibah dari Istana Mangkunegaran. Upacara ini dalam tradisi Hindu kemudian disebut dengan Raja Yadnya.

Menurut Wedakarna, ciri-ciri kebangkitan Hindu Nusantara sesuai dengan ramalan Sabdo Palon Nayogenggong, adalah dengan menyucikan sejarah leluhur. Pada 2012 Wedakarna menyucikan atma leluhur Majapahit di Trowulan. Pada 2013, Wedakarna juga menyucikan atma leluhur Pajajaran di Candi Cangkung-Jawa Barat. Pada 2014, upacara atma Wedana leluhur Mataram di Istana Mangkunegaran Surakarta. Pada 4 Agustus 2015, upacara sedekah bumi dan entas-entas (Pitra Yadnya) diselenggarakan untuk menyucikan arwah leluhur di Kerajaan Sriwijaya di Candi Bumi Ayu Sumatera Selatan. Di Sumatera kini bermunculan candi-candi Hindu seperti Candi Bahal di Sumatera Utara, Candi Muara Takus di Riau, Candi Muara Jambi di Jambi (Bali Post, 5 Agustus 2015).

Wedakarna dapat memanfaatkan jaringan puri-puri di Nusantara. Berbagai kalangan atau kelompok datang menemui Wedakarna untuk menyampaikan harapan, terutama bagaimana puri menjadi simbol pemersatu umat Hindu. Oleh karena itu, secara rutin Wedakarna mendatangi puri-puri di Bali dan juga kelompok-kelompok lain. Sebelum Parisada (Majelis Tinggi Umat Hindu) dibentuk pada 1957, puri-puri di Bali memang sudah berfungsi sebagai pengayom umat
Hindu. Fungsi pengayom umat Hindu kemudian kembali digaungkan oleh Wedakarna.

\section{Ekonomi Satya Graha}

"Warih" Majapahit percaya bahwa Majapahit belum musnah, hanya wilayahnya mengecil yakni Bali (Pranajaya dkk., 2015). Majapahit masih ada, bahkan Bung Karno mengatakan kepada Perdana Menteri India, Jawaheral Nehru ketika berkunjung ke Bali, bahwa Majapahit belum musnah. Majapahit jadi mengecil karena sering terjadi peperangan yang berkepanjangan. Majapahit yang terdiri dari satelit, bawahan, ketika itu memerlukan kepemimpinan yang kuat seperti Gajah Mada dulu.

Menurut Wedakarna, karena rakyat menjadi miskin dibutuhkan kemajuan ekonomi (Satya Graha) dalam hal ini pariwisata untuk menopang kehidupan yang sejahtera. Ketika terjadi perang perebutan tahta di Majapahit antara Keraton Timur dan Keraton Barat, rakyat diajak berperang terus-menerus. Kapan masyarakat dapat membangun ekonomi karena terus terjadi peperangan? Oleh karena itu, rakyat meninggalkan rajanya untuk beralih kepada penguasa baru.

Pemikiran ekonomi Wedakarna tentang Satya Graha di Bali sekarang terwujud dalam kehidupan pariwisata, khususnya pariwisata budaya. Secara ekonomi Bali sudah mandiri dan mampu membiayai upacara-upacara keagamaan. Ekonomi Satya Graha sangat ditopang oleh pariwisata, khususnya pariwisata puri yang berupa tarian, pentas budaya yang mencerminkan budaya Majapahit masa lalu yang sekarang mengalami revitalisasi.

Kebangkitan puri-puri di Bali tidak saja dalam kaitannya dengan identitas politik, tetapi juga berkembang untuk menopang kepariwisataan. Dalam tataran identitas, puri tidak hanya sebagai destinasi utama pariwisata, tetapi juga sebagai pengayom pariwisata budaya yang utama.

Seperti disebutkan di depan, masyarakat Bali dalam perkembangannya jauh berbeda dari tetangganya, yaitu Jawa. Di Bali kemudian terdapat sepuluh kerajaan dengan puri sebagai pusatnya, yang sekarang menjadi daerah kabupaten dan kota. Hal ini seperti yang disebutkan Geertz (1974), bahwa orang Bali cenderung cepat berubah dan 
cepat meniru, mudah menerima sesuatu dari luar dan kemudian menjadikan miliknya sendiri. Terdapat ungkapan "Nak Bali sing kuang daya”, yang artinya Orang Bali tidak pernah kekurangan akal. Oleh karena itu, pariwisata cepat berkembang dan menjadi milik orang Bali yang kemudian terdapat stereotip seakan-akan kehidupan orang Bali semuanya berhubungan dengan pariwisata.

Pelopor pariwisata Bali adalah kalangan aristokrat yang berfungsi sebagai kelas menengah setelah Revolusi 1945. Punggawa Tjokorda Raka Sudarta Raja Ubud (Gianyar) Cokorda Sukawati menjadikan puri sebagai penginapan untuk menjamu tamu-tamu asing seperti Walter Spies dan Rudolf Bonet. Puri dijadikan tempat peristirahatan kemudian menjadi cikal-bakal berdirinya tempat-tempat wisata bergaya villa dan bungalow di Bali. Sementara itu, pada 1920 berdiri Bali Hotel di kompleks Puri Denpasar yang dibangun oleh Belanda (Darma Putra, 1993). Pada 1957 di Sanur, Ida Bagus Kompyang memelopori pembangunan Hotel Segara di tepi pantai. Selanjutnya, Cokorda Ubud dan Ida Bagus Kompiang berkolaborasi dengan senimanseniman asing untuk mempromosikan Bali di luar negeri. Seniman-seniman asing seperti Colin Mc Phee, Jone Belo, Jaap Kunst, Arie Smith, Han Sneel, Mario Blanco, dan lainnya memengaruhi perkembangan pariwisata di Bali khususnya Ubud dan Sanur.

Hampir di setiap kecamatan di Bali terdapat puri, tetapi warih belum dapat memaksimalkan puri sebagai destinasi pariwisata secara maksimal. Keberadaan puri sebagai salah satu destinasi wisata tentu tidak dapat disejajarkan dengan keraton Cirebon, Surakarta, apalagi Yogyakarta. Akan tetapi, wisata puri merupakan kecenderungan pariwisata Bali sekarang, di samping wisata alam. Wisata puri masih dalam lingkup pariwisata budaya yang menjadi ikon pariwisata Bali. Beberapa puri menjadi destinasi pariwisata seperti Puri Mengwi di Badung, Puri Kerambitan di Tabanan, Puri Klungkung di Klungkung, Puri Karangasem di Amlapura, dan juga Puri Ubud. Wisata puri menyuguhkan tarian Bali dan kuliner khas Bali yang disajikan dengan sentuhan modern. Puri juga sebagai pusat seni budaya yang khas. Kesenian-kesenian yang sudah lama umurnya kemudian dikembangkan di puri-puri seperti
Tektekan dan Okokan di Puri KerambitanTabanan (Bali Post, 15 Juni 2016: 14). Di Puri Mengwi dipentaskan beberapa tarian sakral secara regular.

Salah satu ikon identitas Bali adalah pariwisata, khususnya wisata budaya. Selain itu, di Bali juga berkembang jenis wisata alternatif seperti alam, lingkungan, kelautan dan bahkan desa wisata. Secara tidak langsung, pemerintah dan masyarakat Bali juga membentuk zonasi untuk mengidentifikasi jenis wisata yang dikategorikan sebagai wisata alternatif. Hal ini penting agar budaya tetap terjaga menghadapi pariwisata modern dan massal (mass tourism). Pada 2015, Bali dikunjungi oleh 10 juta wisatawan asing dan domestik (Kompas, 4 Januari 2016). Apalagi pada 2016, Bali mendapat predikat pulau wisata terbaik kedua di dunia. Hal ini menunjukkan, bahwa Bali menjadi salah satu pusat perkembangan wisata dunia. Oleh karena itu, gerakan revitalisasi pariwisata budaya Bali turut didukung oleh pihakphak terkait dengan memunculkan jargon "Bali Baru”.

Pariwisata di Bali seakan-akan tidak pernah sepi dengan ragam daya tarik wisata tersendiri. Bali tidak hanya memiliki panorama alam dan budaya yang mampu menarik kunjungan wisatawan, tetapi juga memiliki sejumlah puri (istana) yang mayoritas merupakan duplikasi dari istana Kerajaan Majapahit.

\section{SIMPULAN}

Kerajaan Majapahit yang berbasis Hindu telah lama runtuh. Namun kejayaan Majapahit memberikan kebanggaan, inspirasi, dan simbol perjuangan untuk menegakkan kebangkitan Hindu sesuai dengan ramalan Sabdo Palon Noyo Genggong. Kebangkitan identitas pembangunan citra Hindu sudah ada sejak keruntuhan Majapahit. Beberapa pejuang seperti Trunojoyo mengumandangkan keagungan Majapahit. Peran Majapahit sebagai inspirasi juga berlangsung pada zaman pergerakan awal abad ke-20.

Wacana "Kerajaan Majapahit Bali" dan kebangkitan puri-puri tidak terlepas dari inspirasi yang digaungkan oleh tokoh muda Bali, Arya Wedakarna. Wedakarna tidak saja menjadikan Majapahit dan kebangkitan Hindu sebagai 
inspirasi, tetapi juga untuk membangun politik identitas dan citra diri dalam memperoleh kekuasaan. Memang, politik tidak bisa lepas dari pencitraan dan identitas diri.

Perubahan dan penguatan identitas Bali Bali merupakan hasil perjalanan sejarah yang panjang. Kebijakan pemerintah Belanda yang senantiasa berusaha membedakan Bali dengan daerah lainnya, mewarnai perkembangan Bali dari masa kolonial hingga pascakolonial.

Pada awal abad ini, identitas Bali dianggap cukup progresif dalam rangka mempertahankan eksitensi sebagai salah satu destinasi wisata dunia. Setelah reformasi muncul wacana Bali Merdeka, diikuti dengan wacana Ajeg Bali. Selanjutnya, identitas kontemporer yang dibangun adalah wacana "Kerajaan Majapahit Bali" bersamaan dengan kebangkitan puri-puri di Bali.

\section{CATATAN}

${ }^{1}$ Pendirian sebuah kota biasanya diawali dengan puri sebagai pusat kerajaan sekaligus puri sebagai pusat pemerintahan (Sartono, 1977).

${ }^{2}$ Babad Dalem, Babad Pasek, Babad Buleleng, dan Babad Arya Kuta Waringin.

\section{REFERENSI}

Agung, Ida Anak Agung Gde (1989). Bali pada $A b a d X I X$. Yogyakarta: UGM Press.

Bali Post, 9 Agustus 2015

Bali Post, 23 Agustus 2016

Bali Post, 23 April 2016

Bali Post, 31 Desember 2015

Bali Post, 18 Februari 2018

Bali Post, 1 Juli 2015

Bali Post, 29 Juli 2015

Bali Post, 15 Juni 2016

Bali Post, 19 Maret 2018

Bali Post, 19 November 2015

Berg, C. C. (1926). "Kidung Pamancangah: De Geschiedenis Van het rijk van Gelgel”. Thesis Leiden University.

Creese, Hellen (1993). "The Problem of The Procolonial Balinese State". Paper Presented in a Panel on Autonomous States in Southeast Asia and Korea at $34^{\text {th }}$
International Congress for Asian and North African Studies (ICANAS).

Geldern-Heine, R. (1982). Konsepsi tentang Negara dan Kedudukan Raja di Asia Tenggara. Jakarta: CV. Rajawali.

Geertz, C. (1974). Myth, Symbol, and Culture. New York: Norton.

Geertz, C. (1980). Negara: The Theatre State in Nineteenth-Century Bali. New Jersey: Princeton University Press.

Hilbery, R. (1979). Reminiscences of A Balinese Prince Tjokorda Gde Agung Sukawati. Southeast Asia Paper No. 14 Southeast Asian Studies. University of Hawaii.

Kartodirdjo, Sartono (1977). Masyarakat Kuno Tradisional. Jakarta: Bharata.

Kompas, 4 Januari 2016.

Koran Tokoh, 14 - 20 Nopember 2016.

Mahadewi, I. A. M. (2017). "Dominasi Peran Puri dalam Kontestasi Politik di Bali (Studi Kasus: Puri Agung Denpasar)", Politika, Vol. 1 (1): 1-10.

Majalah Bali Pos, 21-27 Agustus 2017.

Majalah Bali Pos, Juni-Juli 2015.

Mirsha, dkk. (1986). Sejarah Bali. Denpasar: Pemerintah Daerah Tingkat I Bali.

Mulyana, Slamet(1979). Negara Kertagama dan Tafsir Sejarahnya. Jakarta: Bhratara.

Munandar, Agus Aris (2005). Istana Dewa Pulau Dewata: Makna Puri di Bali Abad 14-19. Jakarta: Komunitas Bambu.

Nordholt, Henk Schulte (2006). The Spell of Power: Sejarah Politik Bali 1650-1940. Denpasar: Pustaka Larasan.

Pranajaya, I. Catur Virgiantoro, I Made Budhiarta (2015). Geger Nusantara: Terungkapnya Misteri Gajah Mada dan Terbentuknya Nusantara. Denpasar: Surya Majapahit.

Putra, Nyoman D. (2012). Ida Bagus Kompyang A.A. Mirah Astuti, Pasangan Pioner Pariwisata Bali. Denpasar: Jagat Press.

Putra, Tjokorda R. (2015). Babad Dalem: Warih Ida Dalem Sri Aji Kresna Kepakisan. Denpasar: Pustaka Bali Post.

Robinson, Geoffrey (2006). Sisi Gelap Pulau Dewata: Sejarah Kekerasan Politik. Yogyakarta: LK1S.

Sendra, I Made (2016). "Paradigma Kepariwisataan Bali Tahun 1930-an: Studi Genealogi 
Kepariwisataan Budaya”, Jurnal Kajian Bali,

Vol. 6 (2): 97-124.

Sidemen, Ida Bagus (2010). Dari Wilatikta ke

Swecapura. Yogyakarta: Pustaka Pelajar.

Sidemen, Ida Bagus dkk. (1983). Sejarah

Klungkung: Dari Smarapura sampai

Puputan. Klungkung: Pemerintah Daerah

Tk. II Klungkung.

Staatsblad 1920.

Supomo, R. (1983). “Citra Majapahit dalam

Tulisan Jawa dan Indonesia Kemudian", dalam A. Reid dan D. Marr (ed.) Dari Raja Ali Haji Hingga Hamka, Indonesia dan Masa Lalunya. Jakarta: Grafiti Press.

Wijaya, I. (2009). "Mencintai Diri Sendiri: Gerakan Ajeg Bali dalam Sejarah Kebudayaan Bali, 1910-2007”. Disertasi Program Pascasarjana Fakultas Ilmu Budaya, Universitas Gadjah Mada. 